\title{
Bridging gaps: A framework for developing regional food systems
}

\author{
Daryl Nelligan, ${ }^{a}$ Nairne Cameron, ${ }^{b *}$ Brandon Lee Mackinnon, ${ }^{\mathrm{c}}$ and Carter Vance ${ }^{\mathrm{d}}$ \\ Algoma University
}

Submitted November 29, 2015 / Revised February 9 and August 15, 2016 / Accepted August 16, 2016 /

Published online December 5, 2016

Citation: Nelligan, D., Cameron, N., Mackinnon, B. L., \& Vance, C. (2016). Bridging gaps: A framework for developing regional food systems. Journal of Agriculture, Food Systems, and Community Development, 7(1), 49-69. http://dx.doi.org/10.5304/jafscd.2016.071.007

Copyright (C) 2016 by New Leaf Associates, Inc.

\begin{abstract}
Local food research has been generally focused on strengthening the alternative food system by scaling up local agriculture, rather than advancing strategies to bridge gaps between local farmers and conventional food retail businesses. Competitive advantage theory forms the foundation of a framework based on Porter's (1985) firm (business unit) value chain for investigating food system gaps, and a logic model for promoting development by
\end{abstract}

a Daryl Nelligan, Algoma University; 1520 Queen Street East; Sault Ste. Marie, Ontario, P6A 2G4 Canada; daryl.nelligan@gmail.com

b Corresponding author: Nairne Cameron, Department of Geography and Geology, Algoma University; 1520 Queen Street East; Sault Ste. Marie, Ontario, P6A 2G4 Canada; +1705-949-2301 x4374; nairne.cameron@algomau.ca

c Brandon Lee Mackinnon, Algoma University; 1520 Queen Street East; Sault Ste. Marie, Ontario, P6A 2G4 Canada; brandon.mackinnon@algomau.ca

d Carter Vance, Algoma University; 1520 Queen Street East; Sault Ste. Marie, Ontario, P6A 2G4 Canada.

Carter Vance is now at Carleton University; 1125 Colonel

By Drive; Ottawa, Ontario, K1S 5B6 Canada; cvanc034@gmail.com adding value throughout the alternative food supply chain. In the present study, a survey created jointly by local stakeholders investigated factors that food retail businesses consider when sourcing local food. Among the top rated factors, supporting the local economy (opportunity) and regular delivery (barrier) were seen as significant to the regional food system of the Algoma District in central Canada. Mapping these factors through the firm value chain framework revealed a high degree of interconnectedness to other factors in the survey, including importance of obtaining fresh food, consistency of supply throughout the year, and reducing overall costs of supplying affordable products. Analysis of the survey results from the perspective of a food retail business pointed to information technology and coordinated distribution methods as playing important roles in adding value to the regional food system. In addition to these results, the downtown of the study site has emerged as an aggregation point for local food, and local food may be playing a role in revitalizing the downtown. The value chain framework analysis can be applied to other localities to bridge gaps between local farmers and conventional supply chain actors. 


\section{Keywords}

Alternative Supply Chain; Competitive Advantage Theory; Conventional Supply Chain; Downtown; Framework; Food Delivery; Food Retail; Local Food; Regional Food System; Regional Economy; Porter's Value Chain

\section{Introduction}

Local food is of increasing interest among consumers, governments, nongovernmental organizations, and businesses in Europe and North America, including Canada's Northern Ontario (Knezevic \& Nelson, 2013; Martinez et al., 2010; Nelson \& Stroink, 2013). There is evidence that consumers prefer local production and in some instances will pay more for local products (Carpio \& Isengildina-Massa, 2009; Chinnakonda \& Telford, 2007; Grebitus, Lusk, \& Nayga, 2013) for a variety of reasons, including perceived freshness (Grebitus et al., 2013; Wolf, Spittler \& Ahern, 2005), better taste and/or quality (Chinnakonda \& Telford, 2007; Onozaka, Nurse, \& McFadden, 2010; Wolf et al., 2005), to support the local economy and family farmers (Chinnakonda \& Telford, 2007), perceived environmental sustainability (Kloppenberg, Lezberg, Master, Stevenson, \& Hendrickson 2000), knowledge of the food's supply chain (Marsden, Banks, \& Bristow, 2000; Rikkonen, Kotro, Koistinen, Penttilä \& Kauriinoja, 2013), and perceptions of food safety (Onozaka et al., 2010). Yet local food is not yet routinely and consistently included in the conventional, or "mainstream," food system (Starr et al., 2003).

Direct marketing is common in alternative supply chains. However, there are opportunities and barriers to operating within this model. Some typical direct marketing initiatives include gate sales, u-pick, roadside stands, farmers markets, and community supported agriculture (CSA) (Low et al., 2015). These initiatives present opportunities for farmers to increase their profit margins by selling directly to consumers, avoiding the costs associated with moving product through distribution, processing, and wholesaling firms. However, farmers also face barriers moving in this direction (Mount, 2012). In Southern Australia, Kupke and Page (2015) concluded that farmers are "time poor and spending precious weekends behind a stall does not hold much attraction" (p. 73). Kupke and Page (2015) also comment on the lack of management and staff, and issues around transport and transport costs associated with accessing the market. Moving forward, Guptill and Wilkins (2002) and Abatekassa and Peterson (2011) suggest that more attention needs to be focused at the retail end of the conventional food supply chain. Guptill and Wilkins (2002) state that "researchers and activists must explore the new dynamic retailing landscape in order to formulate strategies for change" (p. 49). Thus bridging gaps between alternative and conventional supply chain actors may expand the market for regional agriculture.

In 2011, the manager of the Johnson Township Farmers' Market, who represented a rural community outside the city of Sault Ste. Marie, Ontario, and who was a member of the Algoma Food Network (AFN), expressed interest in studying the flow of local food into the Sault Ste. Marie marketplace. The AFN is a group of key stakeholders including university faculty, research institutes, citizen groups, farmers market managers, and farmers in the Algoma District of Northern Ontario, Canada. AFN members made up the steering committee for a survey to assess opportunities and barriers in connecting with food retail businesses in Sault Ste. Marie (Algoma Food Network, n.d.). There was informal evidence of local food supply chain activity, and this initial survey was designed to document the extent of local food trade beyond the traditional farmers market, exploring including distribution locations, quality and range of goods, and consistency of availability. The results provided insights for stakeholders and, when considered in the broader context, prompted the conceptualization of a holistic strategy to develop regional food systems. To address failing farmers markets, Sneed and Fairhurst (2010) offered a strategy using competitive advantage theory and applied activity system mapping to strategically position a farmers market within the food retail sector to ensure long-term viability. They propose that "outside advisors are in a position to provide training and assistance to markets in understanding and completing the process of activity system mapping, and using the results to inform future management decisions" 
(Sneed \& Fairhurst, 2010, p. 157). Their application of competitive advantage theory may have broader implications when applied to regional food systems. Porter's (1985) firm value chain, "a collection of activities that are performed to design, produce, market, deliver, and support its product" (p. 36), provides a logical framework to strategically focus regional food systems development. A value chain in this context is not to be confused with popular uses of the term within local food literature, which are typically defined as a common set of values promoting trust and transparency that are practiced among partnering organizations and businesses (Campbell \& MacRae, 2013; Ikerd, 2011; Stevenson \& Pirog, 2008). With Porter's firm value chain framework in place, stakeholder queries were positioned as value activities in Porter's firm value chain based on two assumptions: (1) local food is seen as having a competitive advantage, and (2) local food is differentiated within the market. The stakeholders' survey provided further insights into broader implications for developing regional food systems. Porter's competitive advantage theory, and in particular the value chain framework, can inform survey design that investigates the buying and sourcing practices of food-retail businesses (FRBs), identify areas of the FRB business unit where added value can be created, and provide strategies for a wide range of actors (e.g., food proponents, research centers and institutes, community development corporations [CDCs], business incubators, and business associations). Value activities could be used to bridge gaps between the alternative and conventional supply chain (e.g., including but not limited to farmers, distributors, processors, wholesalers, and retailers only active within the mainstream supply chain). Therefore, Porter's (1985) value chain represents a framework where value activities are actions and interventions that interact and influence desired outcomes that are based on value-added criteria.

\section{Algoma District at a Glance}

Local, when defined as being of provincial provenance, can be a vast distance, particularly within the north of Ontario. The Canadian Food Inspection Agency (CFIA) is adopting an interim policy that defines local food as originating from the province or territory where it is sold, and within a $50-\mathrm{km}$ (31-mile) radius of provincial or territorial borders (Canada Food Inspection Agency, 2014). The province of Ontario's definition for local is consistent with the CFIA version, but it refines the definition as "produced or harvested in Ontario, including forest and freshwater food," or "if they include ingredients produced or harvested in Ontario" (Legislative Assembly of Ontario, 2013, Definitions, sections a and b). For the purposes of this study, local food was defined as being "grown or harvested" in the Algoma District (Figure 1). This limited the scope of local to a smaller unit of study within northern Ontario, and matched the unit with the geographic reach of stakeholders involved. The geographic parameters for the study help to refine the foodshed for Sault Ste. Marie, provide a regional identity, and inform geographic underpinnings of future research in food studies within Northern Ontario.

The Algoma District is a vast area of 48,811 $\mathrm{km}^{2}$ or 18,846 mile ${ }^{2}$ (Statistics Canada, 2012) stretching both north and south of Lake Superior. The city of Sault Ste. Marie, with a population of 75,141 (Statistics Canada, 2012), is located on the border with the U.S. state of Michigan. The city makes up approximately $65 \%$ of the population base of the Algoma District, and thus is its main market (Statistics Canada, 2012). Interest in the regional food system is expanding within the district (Hopper, 2015; Rain Media Release, 2014). The increasing support for a local food economy suggests that there is potential to scale up small to midsized farms, enhance the emerging market, and contribute to a local/regional economy.

\section{Actors in the Algoma District}

\section{Producers}

The Ontario Ministry of Agriculture, Food and Rural Affairs (OMAFRA, n.d.) reported a total of 317 farms in the Algoma District, according to the 2011 census. Most food production occurs in a smaller zone between just north of Sault Ste. Marie and to the southeast, including Blind River and St. Joseph Island (Harry Cummings and Associates, 2009). Products grown in the region include apples, barley, blueberries, broccoli, canola, corn, 


\section{Figure 1. Map of Algoma District}

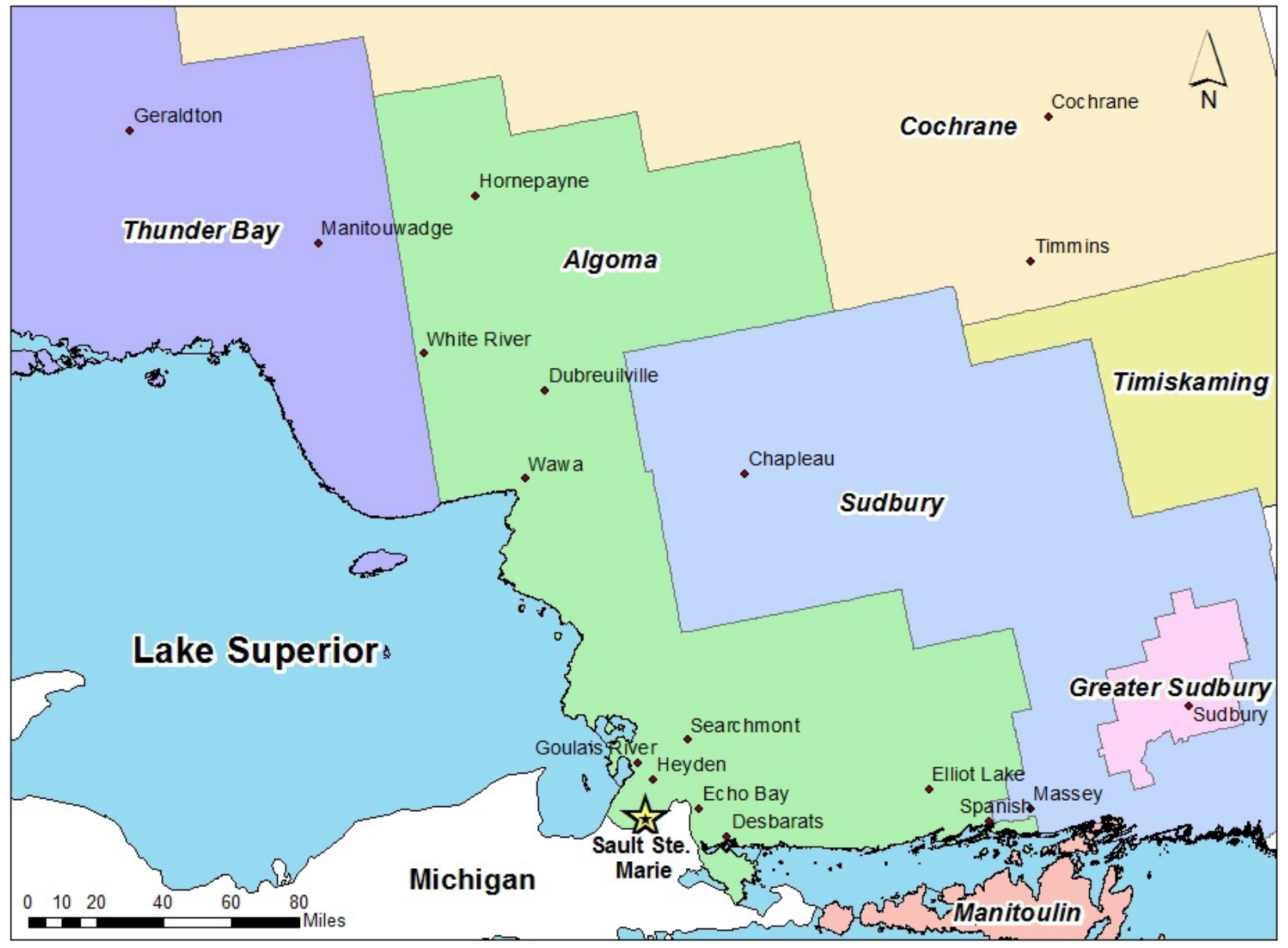

Map prepared using data from:

Statistics Canada. (2011). Boundary Files, 2011 Census. Statistics Canada Catalogue no. 92-160-X [Data set]. Retrieved September 16, 2015, from https://www12.statcan.gc.ca/census-recensement/2011/geo/bound-limit/bound-limit-2011-eng.cfm

Government of Canada, Natural Resources Canada. (2015). Atlas of Canada National Scale Data 1:1,000,000 [Data set]. Retrieved September 18, 2015, from http://geogratis.gc.ca/api/en/nrcan-rncan/ess-sst/-/\%28urn:iso:series\%29atlas-of-canada-national-scaledata-11000000

cucumbers, flax, hay, hemp, mixed grains, oats, root vegetables, soybeans, strawberries, tomatoes, and wheat. Maple syrup is a specialty product of the area. There are also greenhouse, nursery, and floricultural activities, and animal-based farming, including beef and dairy, alpacas, bees, bison, deer and elk, goats, horses, and sheep (Harry Cummings and Associates, 2009; Possibilities Group Inc., 2011; Sault Ste. Marie Innovation Centre, 2012).

The statistics for the district between 2001 and 2011 show that the agricultural community is aging, but there are stable younger generations in the under-35 category (S. Duff, personal commu- nication, March 30, 2015). However, the period between 2001 and 2011 saw a 5.9\% decrease in the number of farms in the district, which is consistent with provincial and national trends (OMAFRA, n.d.). The province showed an increase in gross farm sales of $17 \%$, while the district showed a decrease of $20.2 \%$ over the 2001-2011 period (S. Duff, personal communication, March 30, 2015). Although Sault Ste. Marie is an isolated city, the distance to other markets may actually be an advantage to developing a local market (Nelson \& Stroink, 2013). Following a fact-finding mission in 2002, Mennonites migrated 
from Southern Ontario and established themselves on formerly vacant farms in the Desbarats area in 2003-2004. They were attracted by low land prices and greater land availability, which could lead to opportunities to expand their agricultural base as compared to remaining in Southern Ontario (Farmers' Markets Ontario, 2011; Harris, n.d.). Besides the Mennonites, there does not appear to be an influx of new entrants into the agricultural sector within the district, but the agricultural community appears stable for the time being.

\section{Processors, Wholesalers, and Distributors}

There are few processors, wholesalers, and distributors who deal in local food products within the Algoma District. Two processing facilities are located in the district: one is a meat processing plant that moves meat products in low volumes through meat stores and farmers markets, and the other is an oilseed crushing and processing plant that processes canola into industrial bio-products. One local distribution company transports local dairy products (though not exclusively local) from central collection points in Sudbury $(305 \mathrm{~km}$ or 190 miles from Sault Ste. Marie) and Manitoulin Island (293 km or 182 miles from Sault Ste. Marie). ${ }^{1}$ There is a significant gap among intermediaries in the alternative food supply chain, which is consistent with local food systems literature.

\section{Stakeholders}

Among the stakeholders working toward regional food systems development are the Algoma Food Network (AFN) and the Rural Agri-Innovation Network (RAIN), formed in response to increased interest in local food "dedicated to the needs of agricultural organizations, producers, suppliers and agri-entrepreneurs in Northern Ontario; to enhance the industry by providing a collaborative infrastructure and network that enhances stakeholder capabilities and business growth" (RAIN,

\footnotetext{
${ }^{1}$ Distances between communities, villages, towns, and cities in this paper were calculated using the Ministry of Transportation Ontario's Distance Triangle in combination with Northern Ontario Road Map 12, found on the government website: http://www.mto.gov.on.ca/english/traveller/map/northindex pdf.shtml
}

n.d., para. 2). These stakeholder groups have contributed widely to local food initiatives that include fallen fruit projects (also known as gleaning), campus community gardens, food festivals, community supported agriculture, and farmers markets. In November 2014, the two organizations held the first Sault and Area Food Summit. The event shone a light on a group of "organizations, farmers and every day regular folks who want to "create action and change in the local food system"' (Petroni, 2014, para. 2): the shaping of a community of food practice (Friedmann, 2007).

\section{Retailers}

The food sector in Sault Ste. Marie consists of food retail and food service businesses, such as catering, restaurants, and pre-prepared food services. ${ }^{2}$ Supermarket chains are dominant in the city, and they include two major chains consisting of seven large stores as well as one large independent supermarket. In addition, there are a few small to medium-sized businesses, predominantly located in the downtown, operating as grocery retail stores. ${ }^{3}$ Other store formats include hypermarkets (large stores combining a supermarket with a department store and offering a wide range of goods and services) and drugstores, both of which also offer a limited food selection. Food services also make up a large portion of the food retail sector in the city. Restaurants are dominant within this category and often offer catering services as an additional revenue stream. Specialty food retailers such as bakers, butchers, and health food stores are also present.

Four farmers markets are located in the Algoma District (Algoma Marketing Alliance, n.d.). Two markets that serve Sault Ste. Marie are the

\footnotetext{
2 The definition of food service is taken from Canada Industry Statistics (CIS), which is also the North American Industry Classification System (NAICS) definition. It can be found under the industry Accommodation and Food Services, subsector Food Services and Drinking Places. The definition breaks down further into industry groups. The complete definition can be found at https://strategis.ic.gc.ca/app/scr/ $\underline{\mathrm{sbms} / \mathrm{sbb} / \mathrm{cis} / \text { definition.html? } \mathrm{code}=722 \& \text { lang }=\mathrm{eng}}$

${ }^{3}$ Definition of downtown for the city of Sault Ste. Marie comes from the city's official plan found on the city website: http://www.saultstemarie.ca/City-Hall/City-Departments/ Engineering-and-Planning/Planning/Municipal-Landuse/Official-Plan.aspx
} 
Figure 2. Generic Value Chain Framework, Adapted from Porter's Firm Value Chain

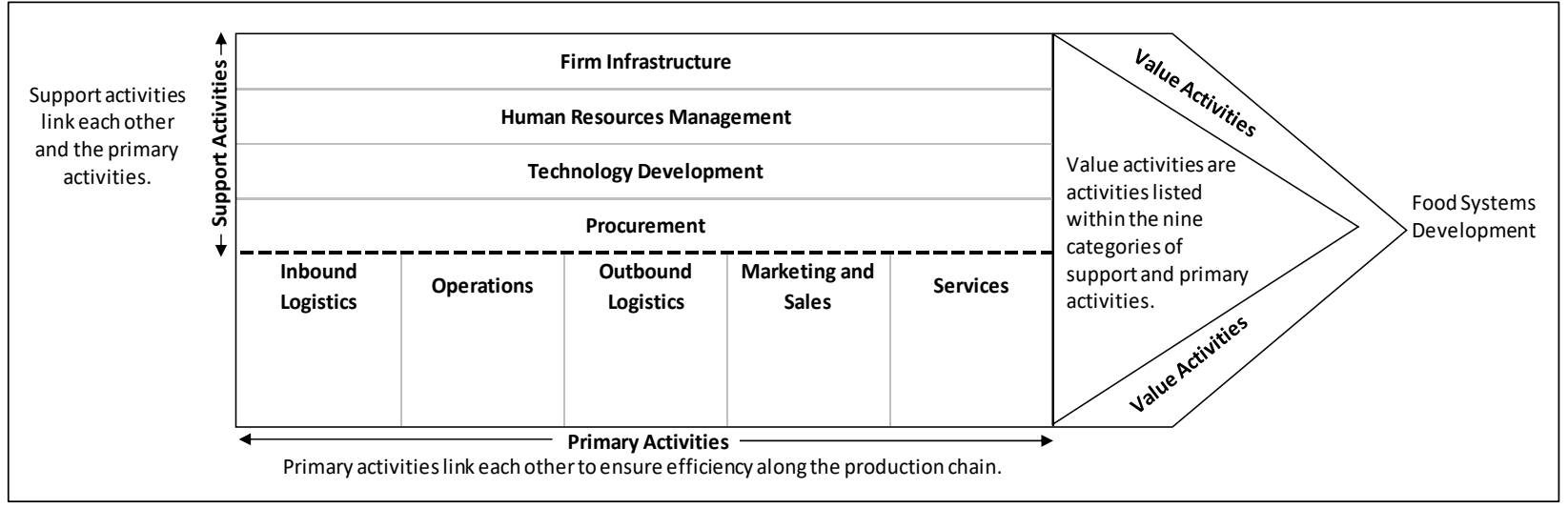

Algoma Farmers' Market and the Mill Market. The former has been operating and offering local food options since 1901 (Taylor, 2014), and in 2001 became affiliated with Farmers' Markets Ontario (Farmers' Market Ontario, 2014). The Mill Market is the newest market, opening in summer 2014. It is a part of the Riversedge Development project in the Historic Canal District of the city. It is not affiliated with Farmers' Market Ontario. These two markets are ways for farmers to engage in direct sales with their customer base in Sault Ste. Marie.

\section{Methodology}

Survey: Design, Sampling Frame, Field

Work, and Quality

Prior to conducting research with human subjects, the Algoma University Ethics Committee approved an ethics application to conduct the research. A questionnaire was developed by the Algoma Food Network consisting of 20 questions that would take approximately five minutes to complete. The FRB population was generated using a sampling frame consisting of telephone directories ${ }^{4}$ and online searches, and through discoveries made in the field. FRBs included in this project were retail outlets, butcher shops, bakeries, health food stores, restaurants, and catering services. Businesses excluded from the sample frame were banquet halls, establishments with a private membership, and convenience stores. The reason for these

${ }^{4}$ The directories used to generate the population of FRBs were the Bell Yellow Pages Telephone Directory (2012) and 411.ca (2012). exclusions are their limited access to the greater public and the requirement for user fees, in the case of banquet halls and establishments with a private membership, as well as the low reliance on convenience stores as a major source of food. Eckert \& Shetty (2011) used a similar participant selection method, which this survey attempted to replicate. While the population identified may not encompass the entire population of FRBs in Sault Ste. Marie, it was the most comprehensive and reliable population estimate. A total of $99 \mathrm{FRBs}$ were identified through the sample framing.

The stakeholders' survey, titled "Locally Grown Food for the Northern Urban Marketplace," was developed by community partners and distributed to FRBs in Sault Ste. Marie. The results of the study are focused on the interests of the stakeholders. Results include types of businesses engaged in local food, purchasing frequency, collection methods, products purchased, important factors to from the point of view of a business owner, and the demand for local food.

Each FRB was contacted by phone and given an incentive to participate. The survey was administered face-to-face due to benefits that included ease in addressing ethical considerations and clarifying survey questions, such as the ability to check for mutual understanding of questions. In many instances, surveys were left with managers to complete at their convenience and retrieved at a later date. Convenience for the participant was an important factor in acquiring completed surveys; restaurants required the most flexibility in terms of survey retrieval. 
Value Chain Framework Analysis:

Analytic Methods

Porter's theoretical concepts in Competitive Advan-

tage: Creating and Sustaining Superior Performance (1985)

were a primary resource for the value chain frame-

work methodology. The framework highlights

opportunities and inadequacies in the local/

alternative food system. In Figure 2, there are nine categories of value activities, with each category representing basic functions of a business. Five categories make up the primary activities, including inbound logistics, operations, outbound logistics, marketing and sales, and services. These primary activities are responsible for "the physical creation of the product and its sale and transfer to the buyer as well as after-sale assistance" (Porter, 1985, p. 38).

Support activities include the following four categories: firm infrastructure, human resources management, technology development, and procurement (Figure 2). Support activities "support the primary activities and each other" (Porter 1985, p. 38). Each of the nine primary and support activity categories ideally includes a process or activity that creates value, or added value. Therefore, they are referred to as value activities. Each category is linked through its value activities. When a value activity is identified within a category, it may require sub-activities that may be assigned to the same category, or to other primary or support activities. For example, if a value activity such as transportation of goods and services is assigned to the primary category outbound logistics, then this activity may require sub-activities. A sub-activity is an action that begins or completes a process, such as driver training and licensing, which could be assigned to the support category human resource management, in addition to falling under the primary category outbound logistics. Therefore, a single value activity is often made up of a complex network of sub-activities, each of which contributes to a complete process.

The survey questions were constructed based on stakeholders' existing knowledge about the complexity and informal nature of the local food system. These questions were assigned to primary and support activity categories. When the questions were organized into the framework, the outcome suggested which categories of the value chain framework needed to be developed or strengthened based on gaps observed by comparing the categories in Porter's framework with the categories represented in the questions from the stakeholder survey. Priorities were set by the results of the survey, which strengthened existing knowledge. Since data was compiled from a large number of FRBs in Sault Ste. Marie, the framework differs from Porter's firm value chain (based on a single business unit), as it represents an aggregate of multiple businesses. The stakeholder input and survey results highlight strengths and weaknesses along the conventional and alternative supply chain and displays opportunities to enhance or eliminate gaps in the regional food system.

\section{Results}

A short growing season, relatively small market size, regional economic focus on resource industries, domination by grocery chains, and minimal local food infrastructure are challenges to local food production and distribution in Algoma District (Harry Cummings and Associates, 2009; Nelson and Stroink, 2013; Possibilities Group Inc., 2011).

\section{FRBs Sourcing Local in the Algoma District}

We approached a total of 99 FRBs to participate in the study, with 51 return surveys, for a response rate of $52 \%$. Fifty-seven percent of FRBs indicated they source locally grown products from the district and 39\% did not; two businesses did not respond. FRBs were split into two categories: food service and food retail. Approximately $75 \%$ of respondents were food service businesses, including restaurants and caterers, and 25\% were food retail businesses, including bakeries, retail outlets, butcher shops, and health food stores. A few FRBs listed a wide range of revenue streams; in most cases they were categorized as food service because their store format fit a food service model. In the food service category, $41 \%$ of total participants source locally, and in the food retail category, 17\% of businesses source locally. Of the total businesses that source locally, $62 \%$ are located in the downtown. The survey also asked if FRB customers were requesting local food; the response rate for 
this question was low, with only $18 \%$ of FRBs responding. The low response rate may indicate a lack of awareness among the consumer base of local food, or lack of concern or awareness by the FRBs in this respect.

The survey also found that FRBs were purchasing local products in the following categories: vegetables $(76 \%)$, meat $(66 \%)$, fruit $(52 \%)$, and maple syrup (48\%). Further inquiry asked FRBs to indicate what specifically they were purchasing in terms of food items within each category except maple syrup, and the majority of business indicated similar products. Purchasing seems to be focused on a few selected food items within each category.

\section{Seasonality of Purchases, and Products Purchased}

The climate of Northern Ontario plays an important role in food production. A longer winter and shorter growing season influence consistency and availability of agricultural products, challenging vegetable growers to provide a consistent supply of produce all year round. Perhaps surprisingly, 52\% of participants indicated sourcing from local farmers all year round (Figure 3). Year-round sourcing of local products could be attributed to the high percentage of participants sourcing meat $(66 \%)$ and just under half the participants sourcing maple syrup. Nearly half of food services (48\%) and the majority of food retailers (63\%) source local products all year round (Figure 3). However, a large proportion of food services (47\%) are sourcing locally on a seasonal basis, from spring to harvest season, while only $13 \%$ of food retailers source locally during the same seasonal time frame (Figure 3). The food retail category appears less active in sourcing local food during the growing and harvest seasons. Just over half the participants sourcing local $(62 \%)$ were located in the downtown: businesses located in the downtown appear to be more active sourcing local food during the growing and harvest seasons. The food service category represents $83 \%$ of the businesses in the downtown, while food services makes up $55 \%$ of business outside the downtown that source local.

In comments regarding the seasonality of purchases in the survey, many participants remarked that they purchase local: when available and needed; whenever available; and as often as available throughout year, as according to the survey response categories. These comments suggest that participants are opportunistic when it comes to sourcing local food. This trend could be a result of local food activity located in the downtown. Generally FRBs source local whenever it is available, but their purchases are focused on specific food items. The larger number of food services captured in the survey may be indicative of focused purchasing. Food services typically offer specialized products as part of a menu or prepared foods; for example, Italian cuisine may require tomatoes, peppers, and beef as base ingredients for most menu items.

\section{Aggregation, Collection, and Distribution}

Figure 4 shows venues (identified by stakeholders) at which collection and aggregation of local food occurs. Based on the responses from participants, the results show that farm gate, fish vendors, and the farmers market are among the most frequented venues by participants sourcing local food. Fiftytwo per cent of participants source local food directly from the farm gate, and $34 \%$ of partici-

\section{Figure 3. Seasonality of Purchases by Participant Type and Location}

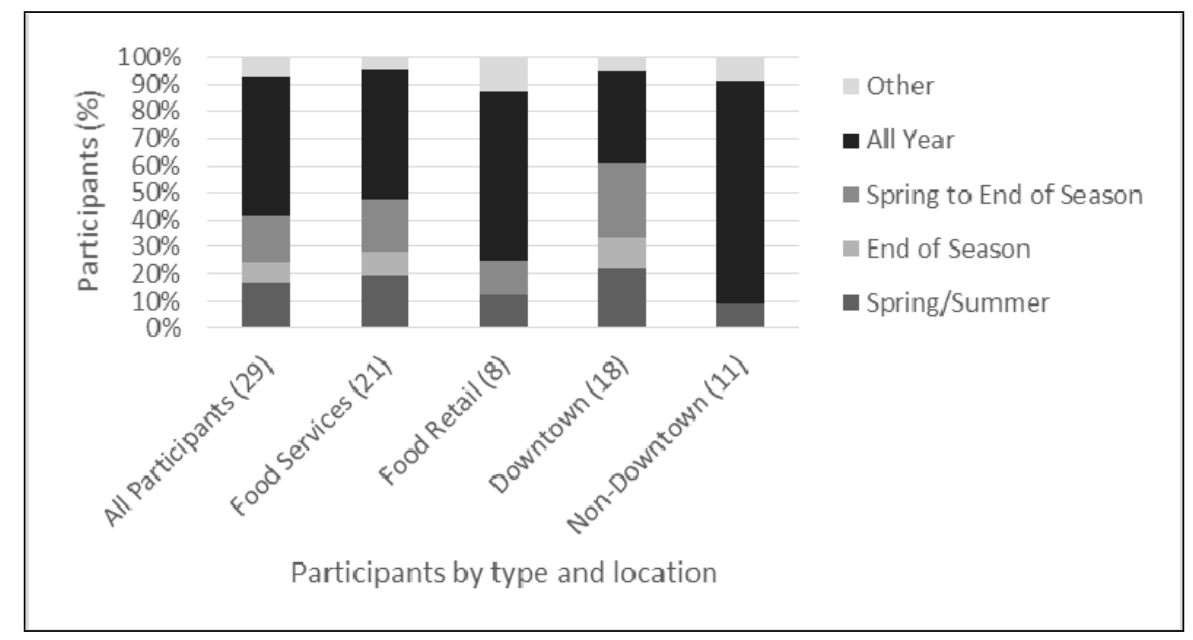


pants source food from a fish vendor and the farmers market. The bulk of participants $(90 \%)$ source from three or fewer different venues, and that $48 \%$ of respondents source from only one of the venues. Among the $48 \%$ sourcing local food from one venue, farm gate still holds as the top venue for sourcing local food. Within the category "other" in Figure 4, collection and aggregation points not included in the list were distribution companies and farmers markets located in adjacent townships.

Stakeholders were interested in how FRBs were sourcing local food from within the district. Figure 5 presents responses on two collection methods commonly used or commonly offered by suppliers in the alternative food supply chain. These methods are delivery, self pick-up, or both. The data were broken down into categories that include all participants, food service vs. food retail,

\section{Figure 4. Collection Centers for Locally Sourced Food}

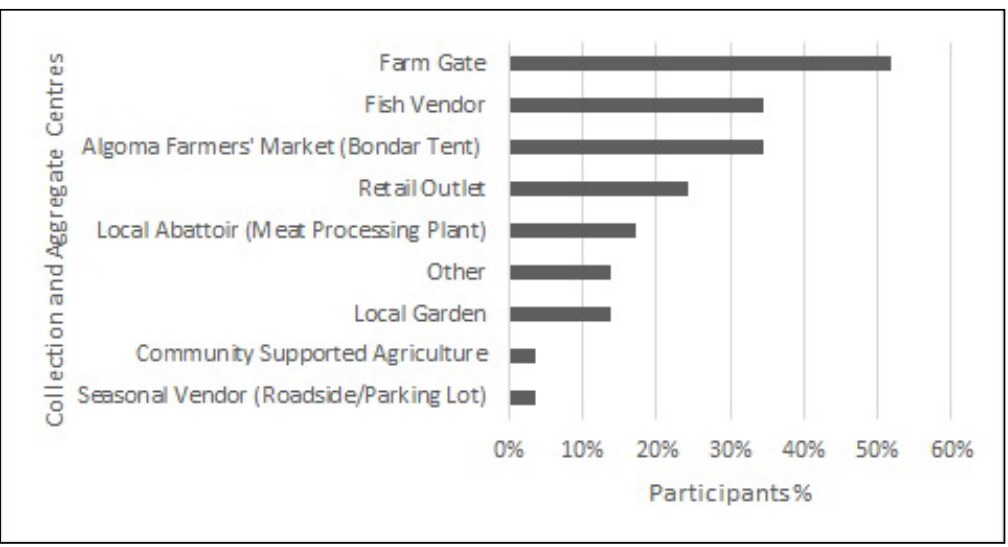

Figure 5. Participants' Collection Methods by Type and Location

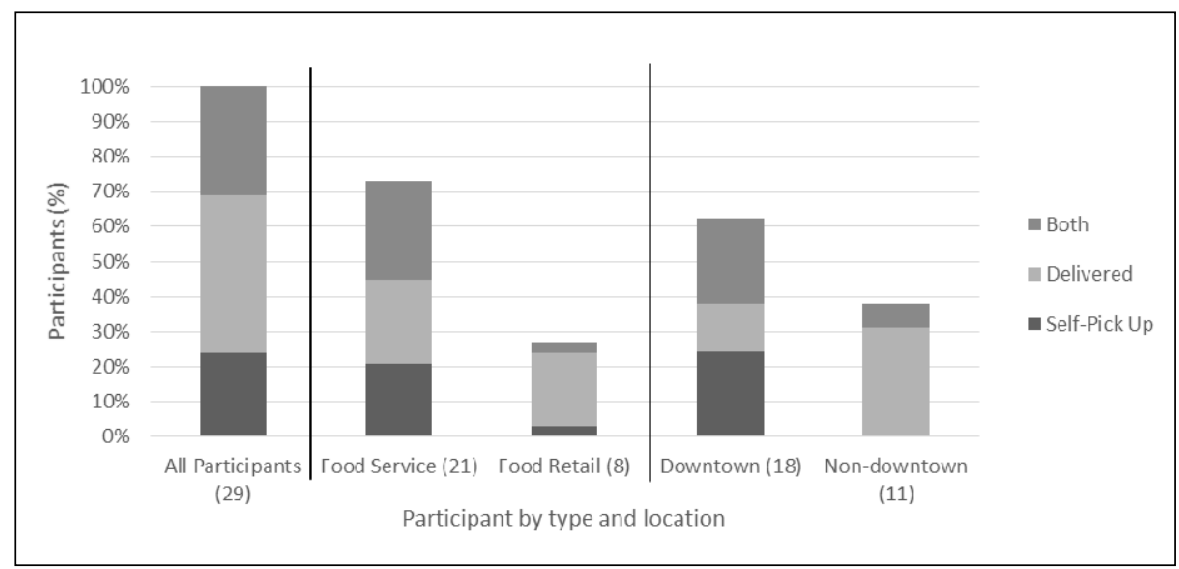

and downtown vs. nondowntown. Approximately $45 \%$ of participants choose delivery as their only method for sourcing local food, despite participants indicating farm gate as the most popular collection point. Second to delivery, $31 \%$ of participants do both pick-up and delivery. When the data were broken down between food services and food retailers, food services are the majority of businesses using self pick-up (48\% including those that do both). Delivery is the predominant method for collection among food retail participants (88\%). When compared between downtown and nondowntown participants, results show that delivery is less common among downtown businesses and more common for businesses located outside the downtown. Collection methods commonly used among participants in the downtown are pick-up $(24 \%)$, or both $(24 \%)$; the majority of participants in the downtown are food services. Outside the downtown, only food services indicated that they do both pick-up and delivery, but $31 \%$ of participants (food services and food retail combined) indicate that delivery is the most common method for sourcing local. The results show that delivery is the general practice among FRBs; however, food services seem to have some degree of mobility, allowing them to use self-pick up as a means of sourcing local products. This is less common among food retail. Evidence supports that the further a business is from the downtown, the less likely it will be to use pick-up as a means of sourcing local products.

Approximately $65 \%$ of 49 FRBs would be interested in picking up local food in a designated location of their choice. Food services represented $70 \%$ of the FRBs interested in picking up local food from a designated area. FRBs commented that pick-up was too much hassle, or they 
would rather have delivery, and they lacked time to pick up local food at a designated area. This reinforces our hypothesis that the greater mobility of food services better allows them to use pick-up as a means to source local products.

Specific locations were given as centers for distribution, aggregation, and collection based on designated areas within the city, taking into consideration existing local food infrastructure and commercial retail centers, as well as potential sites that indicated an absence of local food collection. The following were listed as potential centers for local food collection: Downtown, East End, McNabb/ Great Northern Road Area, New Hospital Area, Steelton, and the Far West End. There were 46 responses, $50 \%$ of which indicated that the Downtown would be a preferred location for distribution, aggregation, or collection of local food. The $\mathrm{McNabb} / \mathrm{Great}$ Northern Road Area (a retail district within the city) was the second choice among FRBs, making up $20 \%$ of the total responses.

\section{Important Factors in Buying Local Food}

Stakeholders were interested in factors that FRBs consider when purchasing local food. Figure 6 shows a list of factors that were rated on a fivepoint Likert scale, where 1 is not important and 5 is very important. The graph represents the percentage of participants indicating how important specific factors were to them as businesses owners. The following were identified as very important factors: obtaining fresh food $(73 \%$ of the business chose very important), supporting the local economy $(69 \%)$, consistency throughout the year $(63 \%)$, getting a better price than what other food suppliers offer (57\%), and regular delivery (55\%). Factors considered to be of lesser importance were being able to sell local food at a premium price (10\% of businesses felt it was very important), establishing short-term contacts for supplying food $(15 \%)$, and obtaining certified organic food (17\%).

\section{Discussion}

The results from the stakeholders' survey provided insights into the nature of the conventional and alternative food systems of a Northern Ontario city. Despite marketing initiatives and the attention that local food has received in Sault Ste. Marie over the last five years, local food was not reported to be in high demand by FRB customers. However, over half the participants stated that they source local food. Food services like restaurants and caterers appear to represent the majority of FRBs and are predominantly located in the downtown area. Coincidently, local food activity and infrastructure seem to be focused in the downtown area, as it is now home to two local food markets, a local food festival, and a number of local food initiatives. It is very likely that the close proximity

\section{Figure 6. Importance of Factors When Sourcing Local Food}

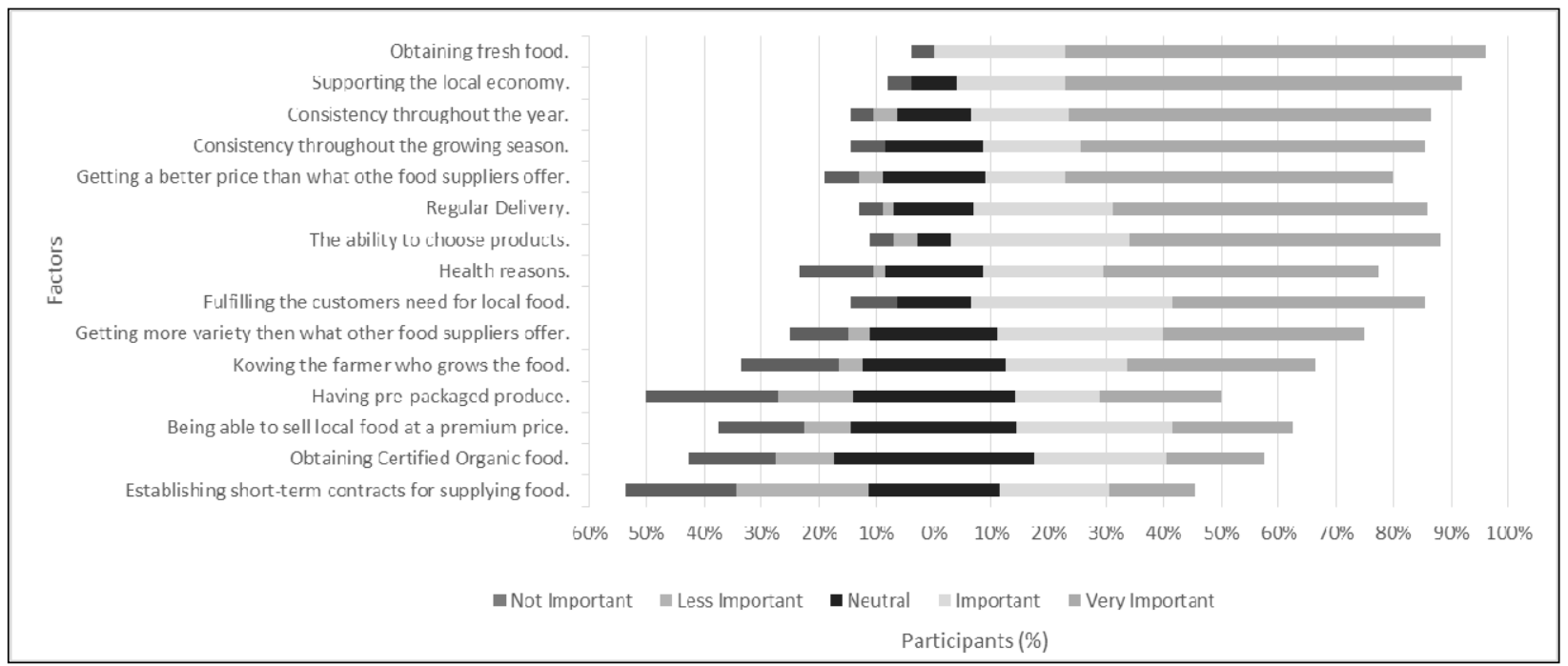


of FRBs to local food aggregation has an influence over their propensity to purchase products throughout the growing season. It is also possible that this particular influence has created opportunities for FRBs to work with specific farmers through informal trust relationships to meet FRB needs.

As mentioned, feedback from the survey detailed specific information for the stakeholders involved in its design. However, the opportunities presented by the survey were only relevant to individual stakeholders. For example, delivery may be a competitive advantage, and farmers already offering delivery know that this is a value-added service. Farmers who do not offer delivery are now privy to knowledge that can expand their market. Porter's (1985) value chain helped to generalize findings and work through a framework to focus local food development. Survey questions were entered into the value chain framework (Figure 7). They were analyzed and assigned to the categories listed under primary and support activities within the framework. The categories of human resources management and technology development in the support activities portion of the diagram in Figure 7 show no data. There was very little input or interest in understanding the human resources management and technological capacity of FRBs. However, when mapping sub-activities, human resources management and technology development became very important in the development of food systems.

Among the value activities listed in Figure 7, obtaining fresh food and consistency in supplying local products and the challenges thereof are well documented in the literature. Two value activities seemed to stand out with local and regional significance. While FRB customers are not requesting local food, FRBs seem to be sourcing local for other reasons. The majority of FRBs indicated that supporting the local economy was very important. Also, due to the geographic expanse of the district, there are logistical issues with collecting, aggregating, and distributing locally raised and grown products. Conventional food supply chains offer the convenience of products being delivered to

Figure 7. Value Chain Framework Using Data from the Stakeholders' Survey

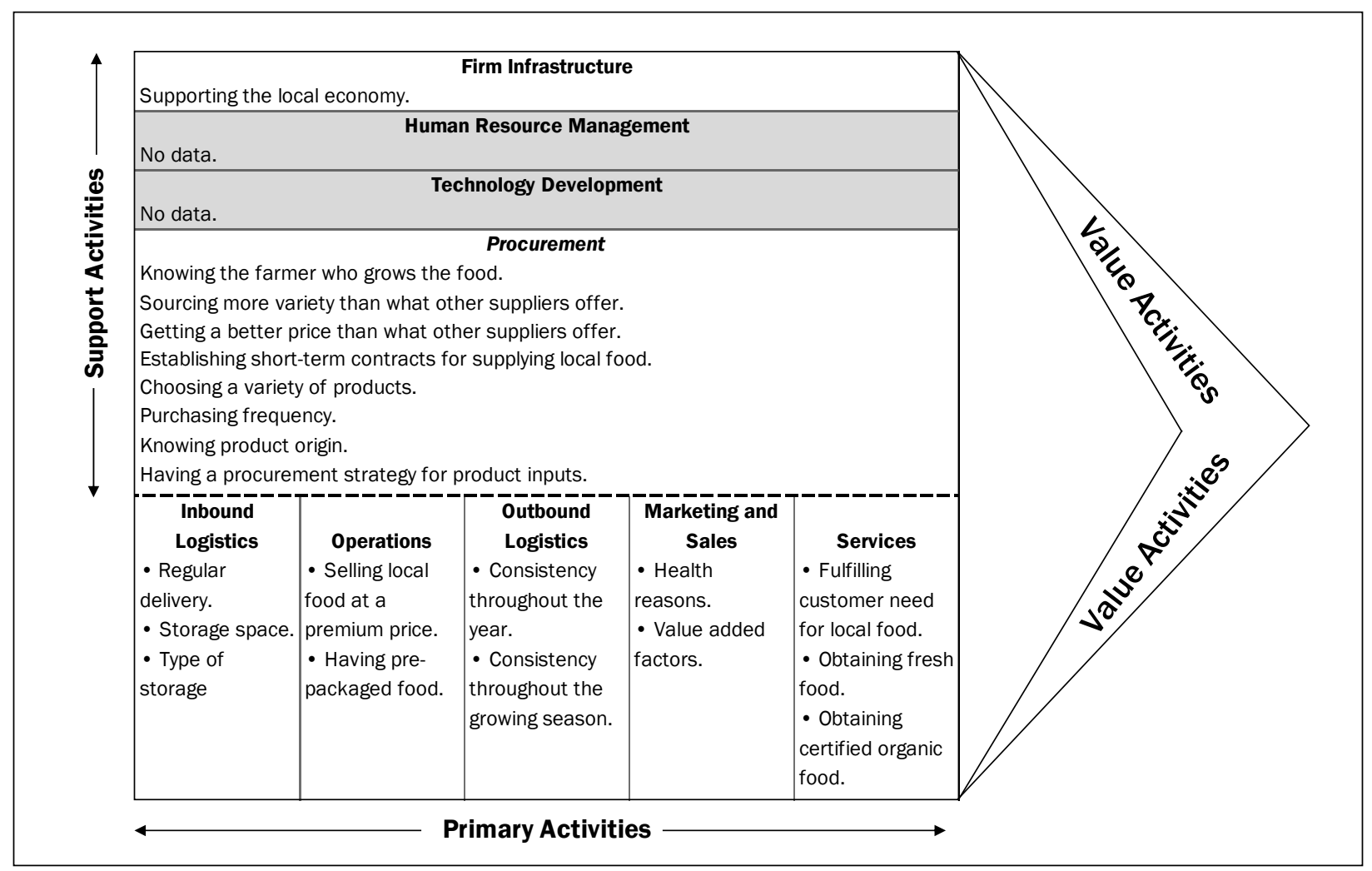


FRBs. This is something that is not as consistent in the alternative food system as seen in Figures 4 and 5. FRBs $(55 \%)$ indicated that regular delivery was very important. An investigation into the local food system revealed that there was very little organized or coordinated aggregation or distribution of local product to the market. Therefore, supporting the local economy and regular delivery are value-added activities for FRBs, but also present challenges for the agricultural community.

These barriers, however, are multifaceted and require a broader scope to overcome. Two prominent themes arise from examining gaps in Figure 7. Gaps in survey coverage of Porter's primary activities indicate less awareness or attention of stakeholders to key processes within a business unit. Referring to Figure 7, there was a lack of questions on the survey related to human resource management and technology development. Many of the businesses surveyed were small to medium-sized businesses with limited staff, therefore some type of subsidized employment (such as one-year internships) would help their operations in key areas. The survey itself did not inquire specifically into the information technology (IT) gap outlined in Figure 7, but there was no evidence of FRBs using IT to create added value to their businesses. The gap in technology development highlights an opportunity for stakeholders to increase their capacity. Using the value chain framework, value activities can be mapped even further to understand how FRBs can create added value by sourcing local foods. This may be through innovation on the part of the FRBs, or it may be an action required by the agricultural community, or both. Either innovation or action becomes a solution and a step toward overcoming barriers to sourcing local food. The following discussion examines the value activities supporting the local economy and regular delivery through the value chain framework from the perspective of an FRB.

\section{Agri-centric vs. Food Retail Business}

Here it is important to understand what is meant by examining barriers to sourcing local food from an FRB's perspective. Local agriculture is reported as contributing significantly to local economies through direct marketing. An overview both within the literature and across a number of local organizations suggests that much of the support for local food economies is focused on the scaling up of local agriculture (upstream) and creating value at the consumer end (downstream). Therefore, development focuses on the agricultural community or through an agri-centric lens (Figure 8). When the stakeholders are positioned so they are taking the perspective of an FRB, as opposed to the perspective of a producer, they are better able to understand consumer preferences as well as barriers to sourcing local food. Bloom and Hinrichs (2011) find similar themes in the United States; they state that "much of this funding is aimed at the traditional thematic areas of rural development and agricultural marketing” (p. 13). Alternatively, an FRB lens (Figure 8) offers a different perspective to understanding barriers that FRBs and the agricultural community face when bridging gaps in the regional food system. To support the local econ-

\section{Figure 8. Food Systems Development Through Agricultural and Food Retailer Lens}

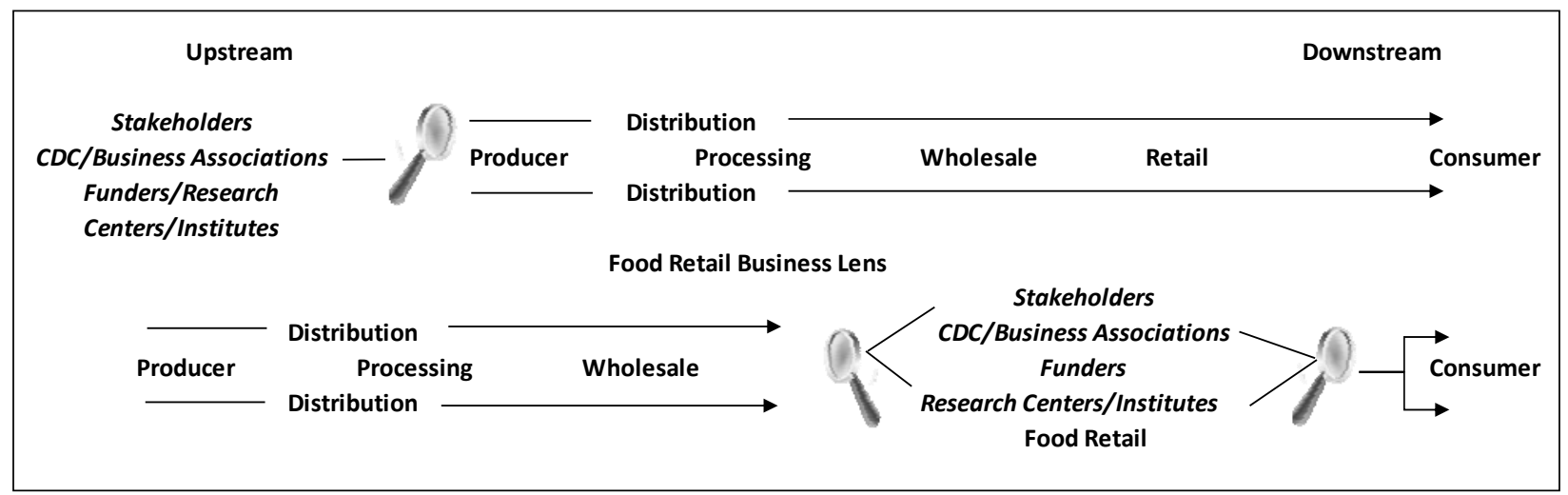


omy and achieve some of the sub-activities mapped in the value chain framework, stakeholders, CDCs, business associations, funders, and research centers and institutes need to divert some attention away from scaling up local agriculture upstream, and focus on the downstream, developing infrastructure for FRBs to source food locally. It should be cautioned, however, that if not properly managed, this may reduce financial returns to farmers by creating additional layers in the value chain.

\section{Example 1: Analysis of a single value activity} using Porter's value chain framework:

\section{Supporting the local economy}

Only 44\% of FRBs felt that fulfilling customer needs was an important factor to consider as a business owner as it related to local food. FRBs placed greater importance on supporting the local economy. Dunne, Chambers, Giombolini, and Schlegel (2010) asked food retailers why they sourced local foods, and they reported that "the most common response was to support the local economy" (p. 50). Dunne et al. (2010) provide a list of motives for food retailers to carry local food, which is consistent with the literature and supports it as a value activity. FRBs feel strongly about supporting the local economy, which creates a positive business image. However, in order for the agricultural community to reciprocate, there needs to be a greater buy-in among FRBs to source local. In other words, there needs to be scaling up through increased sourcing and purchasing of local food. The agricultural community (represented by the stakeholders involved in the survey design) is committed to supplying FRBs with an affordable, high-quality product. However, local agriculture needs significant investment and infrastructure to produce consistent volume year-round at a relatively cheap rate. Figure 9 provides a framework for supporting the local economy.

The principal agents for developing the FRB sector are community development corporations (CDCs); they are the drivers in business development and innovation. Whether it is entrepreneurial support, employment subsidies (interns), or business consulting, CDCs can provide supports and resources for small and medium-sized businesses. Research centers and institutes can also play a role

Figure 9. Mapping Sub-activities Commonly Found in the Literature for the Value Activity "Supporting the Local Economy"

\begin{tabular}{|c|c|c|c|c|c|c|}
\hline \multirow{5}{*}{ 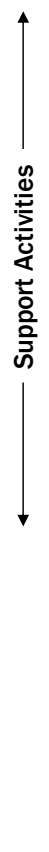 } & \multicolumn{6}{|c|}{$\begin{array}{l}\text { Firm Infrastructure } \\
\text { Accounting can write grants to engage in local food market. } \\
\text { Creating corporate social responsibility-triple bottom line. }\end{array}$} \\
\hline & \multicolumn{6}{|c|}{$\begin{array}{l}\text { Human Resource Management } \\
\text { Writing and using grants; accessing available funding to hire employees to fill gaps, and to engage in the local } \\
\text { food market. } \\
\text { Dedicating employees to be actively engaged in the local food supply chain; food brokers or purveyors. }\end{array}$} \\
\hline & \multicolumn{6}{|c|}{$\begin{array}{l}\text { Pricing software. } \\
\text { Efficient payment method. } \\
\text { Tracking local contribution. }\end{array}$} \\
\hline & \multicolumn{6}{|c|}{$\begin{array}{l}\text { Procurement } \\
\text { Accessing grants or programs that subsidize engaging in local food campaigns or programs. } \\
\text { Pricing scheme; fair pricing. } \\
\text { Defining locally grown and locally purchased. } \\
\text { Purchasing linkages. } \\
\text { Networking with organizations and businesses that enhances the viability of small and medium scale farms. }\end{array}$} \\
\hline & $\begin{array}{l}\text { Inbound Logistics } \\
\text { employment in } \\
\text { distribution, and } \\
\text { direct-store-delivery }\end{array}$ & $\begin{array}{l}\text { Operations } \\
\text { may require } \\
\text { processing and } \\
\text { packaging centers. }\end{array}$ & $\begin{array}{l}\text { Outbound Logistics } \\
\text { assets to expand the } \\
\text { capacity of the } \\
\text { business. }\end{array}$ & $\begin{array}{l}\text { Marketing and Sales } \\
\text { restablishing a } \\
\text { program for sourcing } \\
\text { local. } \\
\text { - Product identity, } \\
\text { local branding. } \\
\text { - Participating in } \\
\text { events celebrating } \\
\text { local agriculture and } \\
\text { local food. }\end{array}$ & $\begin{array}{l}\text { - Developing a food } \\
\text { skills base on local } \\
\text { products. }\end{array}$ & \\
\hline
\end{tabular}


and can partner with FRBs in providing interns, expertise, and resources for developing retail businesses in the local food sector. Government entities can also increase efforts to educate the business community on funding available for local food development. The framework establishes the view of a downstream actor sourcing local food. By building capacity downstream, and by being positioned downstream, barriers can be alleviated and greater opportunities can be created for upstream actors.

Figure 9 draws on academic literature to show what is being done and how development can be focused to overcome barriers by strengthening links between local agriculture and conventional FRBs. It presents solutions on how FRBs can minimize risks by taking the necessary steps to overcome barriers, and it indicates what the agricultural community needs to do in order to add value to FRBs, which overshadows the risks. Figure 9 is based on a literature review that includes Perry, 2011; Rikkonen et al., 2013; Stevenson, Clancy, King, Lev, Ostrom, \& Smith, 2011; Conner et al., 2011; Louden and MacRae, 2010; and Che, Veeck, and Veeck, 2005. A technology gap was identified previously in Figure 7, and furthermore it presents a prominent area for development in the regional food system. Through the development of the value chain framework and cross analysis with the literature, technology plays an important role in creating links between actors in the local food system. Through our engagement with many small and medium-sized FRBs and farmers it was quite clear that, in addition to technology development, the time needed to execute certain functions of a business was lacking. For example, the value activity of engaging in the local food supply chain is a function for which larger chains have entire departments. Therefore, the small and mediumsized FRBs need assistance for this activity, which could be offered through consultation or subsidized employment, such as an internship program.

Many of the respondents are both owners and operators of their FRBs and thus are responsible for a number of functions of their operations. This creates very little room for the self-employed to develop their business beyond its current model because so much time is focused on carrying out day-to-day operations. Figure 9 suggests that hiring grant writers, food brokers or purveyors, and information technologists could assist them in becoming actively engaged in the local food sector. FRBs need funding to employ business innovators in the local food sector. Funding agencies need to tailor funding criteria toward the retail end of the food supply chain.

The value chain framework (Figure 9) identifies a list of activities that would increase FRBs' capacity to source locally. While there are certain challenges in aggregating local food products, aggregating information on local food suppliers is an even greater challenge. Compounding the challenge of aggregating this data is the lack of information on which local food products are offered by various agricultural operations. Creating an organizational body that creates and maintains an online database that houses information like local food suppliers, product availability, price indices, and seed-to-harvest schedules would benefit FRBs, allowing for fair and open competition in the local food sector. Perry (2011) discusses a pricing scheme and schedule for supplying produce and beef to Kentucky State Park system commercial restaurants. The challenges identified by Perry (2011) include prices for goods and payment concerning producers, which were addressed by creating a pricing structure for the produce and the beef sector, and a "feed-to-slaughter schedule" for efficiently supplying beef to food retailers. Abatekassa and Peterson (2011) also suggest that "local product purchasing specifications and guidelines" (p. 57) would benefit the local food system in southeast Michigan. Furthermore, the datahouse would lead to the formation of a network of suppliers, providing greater access to local food.

Purchasing linkages are identified as a support activity as seen in Figure 9. As the data in the stakeholder's survey suggests, local purchases are focused and opportunistic, meaning that FRBs purchase products when they are in season. However, FRBs may require a specific volume or a variety of products not offered by specific farmers. Purchase linkages offer a solution to supplier shortfalls and unavailable products. Purchase 
linkages either could be identified by the FRBs, or referrals could be made by the farmers. For example, if a particular farmer can only supply $80 \%$ of the product volume an FRB requires, that farmer can make a referral to make up the remaining 20\% of the required volume. However, creating purchase linkages between farmers presents the risk of losing sales to a competitor.

One way to reduce this risk is to establish a local food identity or brand, which is also identified in Figure 9. A local food identity means that farmers promote the local brand rather than compete with each other, empowering them to make referrals to other farmers who can fill supply gaps. Under the umbrella of a local identity, informal trust relationships between FRBs and multiple suppliers are deepened, strengthening the local food economy. A local food identity and/or branding strategies can alleviate some of the socioeconomic and environmental issues within the communities they serve through adoption of a corporate social responsibility model. Tregear and Gorton (2009) discuss the theory behind shared brands, or as they refer to it within their limited context, club goods. Tregear \& Gorton (2009) suggest that "shared brands are likely to become more common" (p. 827) because they create stronger brand presence, enhance the credibility of brand claim, and are commonplace among public sector bodies. Balancing stakeholders' interests in brand creation is a challenge, but when brand creation is united through a values-based supply chain with a regional emphasis, cooperation becomes grounded. Local Food Plus, a certifying body that brands local goods, is an example of how to create effective branding strategies (Campbell \& MacRae, 2013; Friedmann, 2007; Louden \& MacRae, 2010).

Analysis of the value activity supporting the local economy becomes clearer from the framework. Working through the framework, stakeholders (e.g., FRBs, CDCs, farmers, and research institutes) can identify key areas to develop within their business model or along the supply chain. Each key area can be linked to more than one subactivity, and all subactivities can be focused toward adding value to the FRBs and extending that value to the consumer. For this value activity, funding employment opportunities for local food innovation and developing IT in this sector will strengthen informal trust relationships along the food supply chain, strengthening the local economy.

\section{Example 2: Analysis of a single value activity using Porter's value chain framework: Regular delivery}

Regional food procurement within the Algoma District presents geographic challenges related to time, distance, efficiency, and cost. The interest groups designed the survey questions to create some depth in understanding challenges FRBs face when procuring local food. Results from the survey indicated that FRBs felt that regular delivery was a very important factor to their businesses. Offering regular delivery is challenging in the district, and the distances farmers may need to travel within the Algoma District to reach markets is a considerable time-cost to them. Farmers located around Sault Ste. Marie's city limits can travel up to $8 \mathrm{~km}$ ( 5 miles) to reach an FRB, and clusters of farmers from Echo Bay (26 $\mathrm{km}$ or 16 miles), Desbarats (46 km or 29 miles) and as far east as Spanish (160 km or 99 miles) have to travel long distances to reach an urban market. North of the city, a producer may travel from Heyden (13 km or 8 miles), Goulais River (25 km or 16 miles), and Wawa (229 km or 142 miles), as well as from greater distances (given the northern expanse of the district) to distribute goods to an urban market (refer to Figure 1).

After analyzing the results and the literature, the distribution and collection of local food would benefit from some organization and coordination. Figure 10 is a value chain framework for mapping the sub-activities of regular delivery, and is based on a literature review, including Bloom and Hinrichs, 2011; Bosona and Gebresenbet, 2011; Green and Dougherty, 2008; and Guptill and Wilkins, 2002. Three key areas of focus become evident from working through the value chain framework: Geographic information system (GIS) software; distribution; and receiving and inventory management.

Considering the geographic expanse of the district, GIS mapping for the purpose of aggregating local food for collection or distribution 


\section{Figure 10. Mapping Sub-activities Commonly Found in the Literature for the Value Activity "Regular Delivery"}

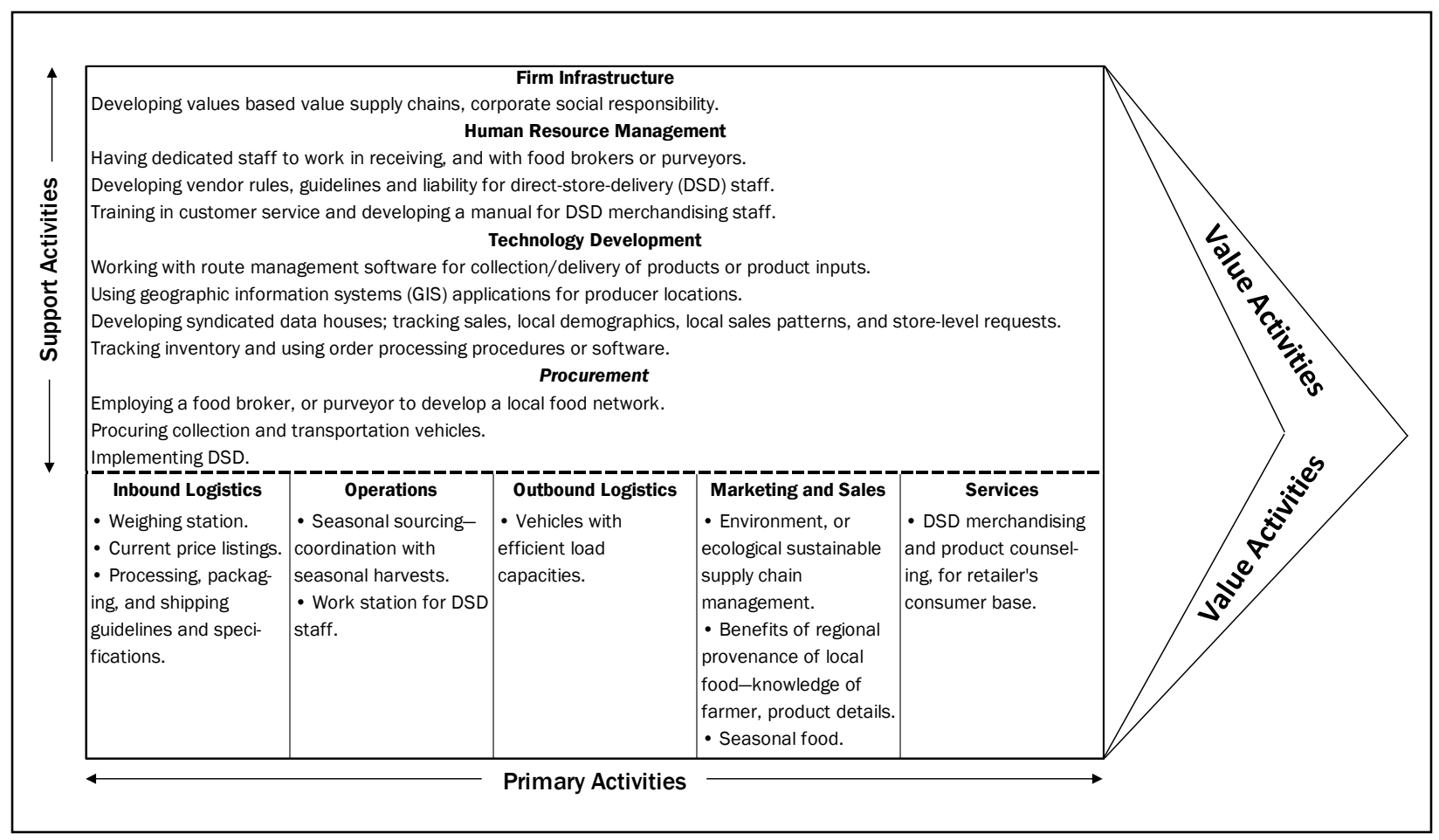

or both would benefit FRBs and farmers. When thinking of a central collection point, the downtown seems to be an ideal location. Approximately $62 \%$ of FRBs that source local food are located in the downtown, so local food infrastructure may already be in place to support a central node. Bosona and Gebresenbet (2011) used route management software and GIS to cluster local producers and map efficient routes to central collections centers in Sweden. The authors concluded that the "clustering and logistics network integration approach...indicated positive improvements in logistics efficiency, environmental impacts, traceability of food quality, and the potential market for local food producers" (p. 301). There are quite a few benefits that come from improving the overall collection methods of local food. By identifying strategic collection centers (since $50 \%$ of FRBs indicated they would pick up local product from a location in the downtown) and analyzing efficient routes, transport costs may be significantly reduced, which may have an effect on the price of local food. Cutting down the food kilometers traveled by each farmer by aggregating local food collection centers along various routes and maximizing distribution loads may also reduce carbon emissions significantly. This would have a positive effect on the environment and would add additional value to a local food product or local food identity or brand.

Continuing with the technological theme, synchronized data warehouses could also benefit both FRBs and the agricultural community. The seasonality of products offered in the district requires a degree of sales forecasting and production intensification. Generating information for the data warehouses may be as simple as FRBs or farmers reporting their sales (both volume and price) to a regulatory agency. If FRBs were equipped with weighing stations and inventory tracking systems, data could be uploaded to a network housed by a regulating agency. This type of data would allow for accurate sales forecasting based on previous years, which benchmarks production inputs and outputs for the agricultural community. Store-level requests and local sales patterns 
combined with information on market segmentation would create increased accuracy in sales forecasting, providing an indication of supply needs.

\section{Conclusion}

Data for the value chain framework analysis tool can come from a variety of sources: surveys, existing research, and academic literature. However, a comprehensive methodology may require setting up an advisory committee of stakeholders from both the conventional and alternative supply chains; developing investigative techniques to understand FRB functions; data analysis; framework development; and strategic planning. The stakeholders' survey in this study required a great deal of resources, including labor, transportation, and time. Shorter paths to acquiring data for the framework may include forming an advisory committee of FRBs that are willing to source local, or conducting key-informant interviews with FRB owners and/or managers. The framework has a wide range of applications: it can be applied as a regionwide local food development strategy, as a business development tool for FRBs and local farmers, and it can be used by research centers and institutes to inform policy and funding criteria for local food initiatives.

The local food movement is creating opportunities for small to midsized farmers to expand their market and increase production through capital investment of on-farm infrastructure. Alternative food systems typically establish direct links between farmers and their consumers, where gaps in distribution and wholesaling are commonplace. As such, development in the local food sector is often focused on initiatives that assist local agriculture in adding value for the end consumer. This type of development is largely agri-centric, focusing on the marketability of the production processes of small to midsized farms. Marketing initiatives rely heavily on branding strategies that label products as healthy or environmentally sustainable, which can switch consumer purchasing habits, but farmers incur costs by having to adapt their business model to fit the criteria of various branding strategies. These costs may include additional inputs, fees, time costs, and labor. A food retail lens offers a perspective to local food system development that adds value throughout the alternative supply chain.

Addressing divergent interests in local food systems development is a challenging task. The value chain framework allows stakeholders in food systems development to develop a comprehensive knowledge of the functions of food retail businesses within their localities. By understanding the different functions of food retail businesses and their relative importance to the business, stakeholders can execute value activities that add value to the businesses they supply. The examples of two value activities outlined in this paper suggest that within the context of the study site, funding employment opportunities for local food business innovation, and developing information technology in this sector will strengthen informal trust relationships between conventional supply chain actors and local farmers. A coordinated distribution system that centralizes the aggregation of local food products also can add considerable value along the alternative supply chain. Overall improvement in the category of IT would enhance the supply chain, making it more attractive to FRBs and thus adding value to their businesses.

When considering a development strategy based on the assessment of value activities in the framework, an asset-based community development approach (Mathie \& Cunningham, 2003) should be considered. Within the study site, the downtown is a center for local food activity, and existing infrastructure becomes a community asset. Clearly, the two local food markets located in the downtown are influential in channeling local food to FRBs, and stakeholders should consider the downtown the focus of future food systems development. Many mature downtown areas of cities across North America, including in Sault Ste. Marie, are experiencing an out-migration of investment to the suburbs (Corporation of the City of Sault Ste. Marie, 2015). Sault Ste. Marie's downtown is emerging as an aggregation center for local agriculture. This has implications for the role of local food as part of a revitalization strategy for drawing community members into the city's downtown, and also implications for stimulating a downtown economy utilizing a multi-use development strategy where local food is the driving force. 


\section{Acknowledgments}

The authors would like to acknowledge the stakeholders-Northern Ontario Research Development Ideas Knowledge (NORDIK) Institute, Algoma Food Network (AFN), Johnson Farmers' Market Desbarats, and independent farmers - for their collaboration in survey design and for providing advice, assistance, and resources throughout our research. We would also like to thank Algoma University's Geography and Geology Department for providing resources to conduct field work and carry out the research. Acknowledgements also to David Thompson, Katrina Holkko, and Steve Piazza for their contributions in data collection and collaboration on the project.

\section{References}

Abatekassa, G., \& Peterson, H. C. (2011). Market access for local food through the conventional food supply chain. International Food and Agribusiness Management Review, 14(1), 63-82. http://purl.umn.edu/100876

Algoma Food Network. (n.d.). Buy Algoma, buy fresh. Retrieved September 11, 2015, from http://buyalgoma.ca/afnet

Algoma Marketing Alliance. (n.d.). Local products directory [Brochure]. Retrieved October 23, 2014, from www.buyalgoma.ca/images/localproducthigh.pdf

Bloom, J. D., \& Hinrichs, C. C. (2011). Moving local food through conventional food system infrastructure: Value chain framework comparisons and insights. Renewable Agriculture and Food Systems, 26(1), 13-23. http://dx.doi.org/10.1017/S1742170510000384

Bosona, T. G., \& Gebresenbet, G. (2011). Cluster building and logistics network integration of local food supply chain. Biosystems Engineering, 108(4), 293-302. http://dx.doi.org/10.1016/i.biosystems eng.2011.01.001

Campbell, A. M., \& MacRae, R. (2013). Local Food Plus: The connective tissue in local/sustainable supply chain development. Local Environment, 18(5), 557-566.

http://dx.doi.org/10.1080/13549839.2013.788488

Canadian Food Inspection Agency. (2014, September 23). Local food claims interim policy. Retrieved March 5, 2015, from http:/ / www.inspection.gc.ca/ food/labelling/food-labelling-for-industry/origin/ local-food-claims/eng/1368135927256/ $\underline{1368136146333}$
Carpio, C. E., \& Isengildina-Massa, O. (2009). Consumer willingness to pay for locally grown products: The case of South Carolina. Agribusiness, 25(3), 412-426. http://dx.doi.org/10.1002/agr.20210

Che, D., Veeck, A., \& Veeck, G. (2005). Sustaining production and strengthening the agritourism product: Linkages among Michigan agritourism destinations. Agriculture and Human Values, 22(2), 225-234. http:/ / dx.doi.org/10.1007/s10460-004$\underline{8282-0}$

Chinnakonda, D., \& Telford, L. (2007). Local and regional food economies in Canada: Status report. Retrieved from Agriculture and Agri-food Canada (AARC) website: http://www4.agr.gc.ca/resources/prod/doc/pol/ $\mathrm{pub} /$ econ can/pdf/econ can e.pdf

Conner, D. S., Nowak, A., Berkenkamp, J., Feenstra, G. W., Van Soelen Kim, J., Liquori, T., \& Hamm, M. W. (2011). Value chains for sustainable procurement in large school districts: Fostering partnerships. Journal of Agriculture, Food System, and Community Development, 1(4), 55-68. http://dx.doi.org/10.5304/jafscd.2011.014.005

Corporation of the City of Sault Ste. Marie. (2015). Downtown development. Retrieved September 9, 2015, from http://www.saultstemarie.ca/CityHall/City-Departments/Engineering-andPlanning/Planning/Strategic-Long-RangePlanning/Downtown-Development.aspx

Dunne, J. B., Chambers, K. J., Giombolini, K. J., \& Schlegel, S. A. (2011). What does "local" mean in the grocery store? Multiplicity in food retailers' perspectives on sourcing and marketing local foods. Renewable Agriculture and Food Systems, 26(1), 46-59. http://dx.doi.org/10.1017/S1742170510000402

Eckert, J., \& Shetty, S. (2011). Food Systems, planning and quantifying access: Using GIS to plan for food retail. Applied Geography, 31(4), 1216-1223. http://dx.doi.org/10.1016/j.apgeog.2011.01.011

Farmers' Markets Ontario. (2011). Profile: Edith Orr, market manager. Market Matters, 10, 3. Retrieved from http://www.farmersmarketsontario.com/ Newsletters.cfm?uNewsID $=10$

Farmers' Markets Ontario (2014). Farmers' markets Ontario. Retrieved May 27, 2013, from http://www.farmersmarketsontario.com/MarketD etails.cfm?uSearchString $=$ \&uPageNum $=1$ \&uMarke $\underline{\mathrm{tID}=15}$ 
Friedmann, H. (2007). Scaling up: Bringing public institution and food service corporations into the project for a local, sustainable food system in Ontario. Agriculture and Human Values, 24(3), 389398. http://dx.doi.org/10.1007/s10460-006-9040-2

Grebitus, C., Lusk, J. L., \& Nayga, R. M., Jr. (2013). Effect of distance of transportation on willingness to pay for food. Ecological Economics, 88, 67-75. http://dx.doi.org/10.1016/j.ecolecon.2013.01.006

Green, G. P., \& Dougherty, M. L. (2008). Localizing linkages for food and tourism: Culinary tourism as a community development strategy. Community Development, 39(3), 148-158. http://dx.doi.org/10.1080/15575330809489674

Guptill, A., \& Wilkins, J. L. (2002). Buying into the food system: Trends in food retailing in the US and implications for local foods. Agriculture and Human Values, 19(1), 39-51. http://dx.doi.org/10.1023/A:1015024827047

Harris, S. (n.d.). Discover Mennonite goods at the farmers market-Where tradition meets commerce. Retrieved May 25, 2013, from http://www.sault tourism.com/extras/index.aspx?1=0,21,39,49

Harry Cummings and Associates. (2009). AlgomaManitoulin agricultural economic sector profile. Retrieved from Harry Cummins and Associates website: http://www.hcaconsulting.ca/pdfs/2009 Algoma Manitoulin Agri Economic Impact.pdf

Hopper, D. (2015, August 31). Eating Algoma. SooToday.com. Retrieved from http://www.sootoday. $\mathrm{com} /$ content $/$ news $/$ details.asp?c $=97155$

Ikerd, J. (2011). Essential principles of sustainable food value chains. Journal of Agriculture, Food Systems, and Community Development, 1(4), 15-17. http://dx.doi.org/10.5304/jafscd.2011.014.001

Kloppenberg, J., Jr., Lezberg, S., De Master, K., Stevenson, G., \& Hendrickson, J. (2000). Tasting food, tasting sustainability: Defining the attributes of an alternative food system with competent, ordinary people. Human Organization, 59(2), 177186. http://dx.doi.org/10.17730/humo.59.2. $\underline{8681677127123543}$

Knezevic, I., \& Nelson, E. (2013). Introduction. In I. Knezevic, K. Landman, A. Blay-Palmer, A., \& E. Nelson (Eds.), Models and best practices for building sustainable food systems in Ontario and beyond (pp. 8-15). Guelph, Ontario, Canada: Ontario Ministry of Agriculture, Food and Rural Affairs. Retrieved from http:// nourishingontario.ca/models-andbest-practices
Kupke, V., \& Page, G. (2015). Does the farmer want a market? Factors impacting on participation by local producers in farmers markets. Pacific Rim Property Research Journal, 21(1), 61-75. http://dx.doi.org/10.1080/14445921.2015.1026199

Legislative Assembly of Ontario. (2013, November 6). Bill 36 Local Food Act, 2013. Retrieved from http://www.ontla.on.ca/web/bills/bills detail.do? locale $=$ en $\&$ BilliD $=2754$

Louden, F. N., \& MacRae, R. J. (2010). Federal regulation of local and sustainable food claims in Canada: A case study of Local Food Plus. Agriculture and Human V alues, 27(2), 177-188. http://dx.doi.org/10.1007/s10460-009-9209-6

Low, S. A., Adalja, A., Beaulieu, E., Key, N., Martinez, S., Melton, A.,...Jablonski, B. B. R. (2015). Trends in U.S. local and regional food systems: Report to Congress (AP No. 68). U.S. Department of Agriculture, Economic Research Service. Retrieved from https://www.ers.usda.gov/publications/pubdetails $/$ ?pubid $=42807$

Marsden, T., Banks, J., \& Bristow, G. (2000). Food supply chain approaches: Exploring their role in rural development. Sociologia Ruralis, 40(4), 424-438. http://dx.doi.org/10.1111/1467-9523.00158

Martinez, S., Hand, M. S., Da Pra, M., Pollack, S., Ralston, K., Smith, T.,... Newman, C. (2010). Local food systems: Concepts, impacts, and issues (ERR No. 97). U.S. Department of Agriculture, Economic Research Service. Retrieved from https://www.ers.usda.gov/publications/pubdetails / ?pubid $=46395$

Mathie, A., \& Cunningham, G. (2003). From clients to citizens: Asset-based Community Development as a strategy for community-driven development. Development in Practice, 13(5), 474-486. http://dx.doi.org/10.1080/0961452032000125857

Mount, P. (2012). Growing local food: Scale and local food systems governance. Agriculture and Human Values, 29(1), 107-121. http://dx.doi.org/10.1007/s10460-011-9331-0

Nelson, C., \& Stroink, M. (2013). Northern Ontario. In I. Knezevic, K. Landman, A. Blay-Palmer, A., \& E. Nelson (Eds.), Models and best practices for building sustainable food systems in Ontario and beyond (pp. 1667). Guelph, Ontario, Canada: Ontario Ministry of Agriculture, Food and Rural Affairs. Retrieved from http://nourishingontario.ca/models-andbest-practices/ 
Onozaka, Y., Nurse, G., \& McFadden, D. T. (2010). Local food consumers: How motivations and perceptions translate to buying behavior. Choices, 25(1), 1-6. Retrieved from http://www.choices magazine.org $/$ magazine $/$ article.php?article $=109$

Ontario Ministry of Agriculture, Food and Rural Affairs [OMAFRA]. (n.d.). Number of census farms by county, 1991, 1996, 2001, 2006, 2011 [Table]. Retrieved from http://www.omafra.gov.on.ca/ english/stats/census/cty30.htm

OMAFRA. (2007). Census farms classified by size of operation, by county, 2006 [Table]. Retrieved from http://www.omafra.gov.on.ca/english/stats/ census/cty33.htm

Perry, R. R. (2011). Agricultural development is economic development: Kentucky State Parks local food purchasing case study. Journal of Agriculture, Food Systems, and Community Development, 1(4), 3-13. http://dx.doi.org/10.5304/jafscd.2011.014.010

Petroni, S. (2014, November 19). Eat local all year long: Sault and Area Food Summit. Northern Hoot. Retrieved from http:// northernhoot.com/eat-localyear-long-sault-area-food-summit/

Porter, M. E. (1985). Competitive advantage: Creating and sustaining superior performance. New York: Free Press.

Possibilities Group Inc. (2011). Development of a Rural Agricultural Innovation Network pilot in the Algoma District: Terms of reference. Sault Ste. Marie Innovation Centre. Retrieved from http://www.nordikinsti tute.com/wp-content/uploads/2012/01/AlgomaRAIN-Pilot-Project-Terms-of-Reference-February2011.pdf

Rain Media Release (2014, November 11). Food summit to attract organic and local growers. Sault This Week. Retrieved from http://www.saultthisweek.com/ 2014/11/11/food-summit-to-attract-organic-andlocal-growers

Rural Agri-Innovation Network [RAIN]. (n.d.). About RAIN. Retrieved November 12, 2016, from http://rainalgoma.ca/rain-agriculture/

Rikkonen, P., Kotro, J., Koistinen, L., Penttilä, K., \& Kauriinoja, H. (2013). Opportunities for local food suppliers to use locality as a competitive advantageA mixed survey methods approach. Acta Agriculturae Scandinavica: Section B-Soil \& Plant Science, 63(Suppl. 1), 29-37.

http://dx.doi.org/10.1080/09064710.2013.783620
Sault Ste. Marie Innovation Centre. (2012). Report on the findings-Implementing the Algoma Rural Agriculture Innovation Network (RAIN) pilot project. Retrieved from http://www.nordikinstitute.com/wpcontent/uploads/2012/01/Algoma-RAINStakeholder-Discussion-Paper.pdf

Sault Ste. Marie Innovation Centre. (2013). RAIN. Retrieved May 27, 2013, from http://www.ssmic. $\mathrm{com} /$ index.cfm? fuseaction $=$ content $\&$ menuid $=$ 40\&pageid $=1264$

Sneed, C. T, \& Fairhurst, A. E. (2010). From the boardroom to the farmers' market: Using activity system mapping to explore a farmers' market competitive advantage. Journal of Agriculture, Food Systems, and Community Development, 1(1), 149-159. http://dx.doi.org/10.5304/jafscd.2010.011.015

Starr, A., Card, A., Benepe, C., Auld, G., Lamm, D., Smith, K., \& Wilken, K. (2003). Sustaining local agriculture barriers and opportunities to direct marketing between farms and restaurants in Colorado. Agriculture and Human V alues, 20(3), 301321. http://dx.doi.org/10.1023/A:1026169122326

Statistics Canada. (2012). Census profile: Sault Ste. Marie, Ontario (Code 3557061) and Algoma, Ontario (Code 3557) [Table]. Retrieved May 25, 2013, from http://www12.statcan.gc.ca/censusrecensement/2011/dp-pd/prof/details/page.cfm? Lang $=\mathrm{E} \& \mathrm{Geo} 1=\mathrm{CSD} \& \mathrm{Code} 1=3557061 \& \mathrm{Geo} 2=\mathrm{C}$ D\&Code $2=3557 \&$ Data $=$ Count $\&$ Search Text $=$ sault $\% 20$ ste. $\% 20$ marie $\&$ Search Type $=$ Begins $\&$ SearchPR $=35 \& \mathrm{~B} 1=$ All $\&$ Custom $=\& \mathrm{TABID}=1$

Stevenson, G. W., Clancy, K., King, R., Lev, L., Ostrom, M., \& Smith, S. (2011). Midscale food value chains: An introduction. Journal of Agriculture, Food Systems, and Community Development, 1(4), 27-34. http://dx.doi.org/10.5304/jafscd.2011.014.007

Stevenson, G. W., \& Pirog, R. (2008). Values-based supply chains: Strategies for agrifood enterprises of the middle. In T. A. Lyson, G. W. Stevenson, \& R. Welsh (Eds.), Food and the mid-level farm: Renewing an agriculture of the middle (pp. 119-143). Cambridge, Massachusetts: MIT Press. http://dx.doi.org/ 10.7551/mitpress/9780262122993.003.0007

Taylor, D. (2014, April 11). Farmers market staying put, Mill Market to proceed. SooToday.com. Retrieved from http://www.sootoday.com/content/news/ details.asp? $\mathrm{c}=71550$ 
Journal of Agriculture, Food Systems, and Community Development ISSN: 2152-0801 online

http://www.foodsystemsjournal.org

Tregear, A., \& Gorton, M. (2009). The challenges of sharing: Brands as club goods. European Journal of Marketing, 43(5/6), 826-842.

http://dx.doi.org/10.1108/03090560910947061
Wolf, M. M., Spittler, A. \& Ahern, J. (2005). A profile of farmers' market consumers and the perceived advantages of produce sold at farmers' markets. Journal of Food Distribution Research, 36(1), 192-201. Available from http://purl.umn.edu/26768 